\title{
A CORRELATIONAL STUDYON THEIMPACT OF STUDENTS' ENGLISH ACHIEVEMENT ON STUDENTS' RESIDENCE
}

\author{
Muhammad Iqbal Ripo Putra \\ IKIP-PGRI Pontianak \\ ripoputra87@gmail.com \\ Sulaiman \\ IKIP-PGRI Pontianak
}

\begin{abstract}
The purposes of this research are to reveal: (1) the students' English achievement; (2) the relationship between students' residence and students' English achievement; and (3) the significant relationship between students' residence and students' English achievement. The researchers used correlational research design as the design of this research. The population of this research is 112 students of the tenth grade of SMAN 1 Silat Hulu and the total number of sample are 60 students who are chosen by using stratified sampling technique. The instruments used questionnaire and documentation. Based on the result of research finding and discussion in this research, it can be concluded that the average of English achievement of the students' who live with parents was higher than the students who live with no-relative and there are a significant correlation between students' residence and students' English achievement.
\end{abstract}

Key word: students' residence, students' English achievement, correlational research

\section{INTRODUCTION}

Getting a good achievement in learning is a pride for all students. In order to get it, they have to pass the learning process and do many activities as their duties which have to be done, for example study at school, do the exercise, homework, group assignment, preparing for the exam, etc., especially in English subject the students have to do many things either theoretically or practically. Therefore, the students have to do more effort in order to get good score in English. It is not enough for them only study at school, but they also have to practice and study English at home. It means that the students need more time to study English at home as well.

However, a home plays an important role for a student's learning. Collins (2007: 32) defined a home as a place where pupils live with their parents or guardian and it is the place where they are groomed. It is a place where the pupils begin to learn the norms and values of the society in which they find themselves. Supporting to the definition, Ogbemudia and Aiasa (2013: 121) argue that home 
environment is the immediate surroundings in which the pupils find themselves. It is also referred to as the physical and psychological conditions that affect children. The parents of the students are responsible for providing the right home environment that will facilitate effective learning for their children. The home environment means the family background of the students; this includes all the human and material resources present at the home that affects the student's education and living. The home environment also plays a very remarkable role in the life and educational success of every individual (Egunsola, 2014: 47).

Unfortunately, many students of SMAN 1 Silat Hulu especially the tenth grade students are not able to live at home with their parents or relatives. They live with a person who is not their relatives while they are attending school in Silat Hulu district. There are many things that cause this phenomenon. First, their domicile or village is located far from school. Second, the geographic condition and the accessibility from the students' domicile to the district also make the parents have to think deeply about the best way for their children to be obtained study at SMAN 1 Silat Hulu as the only one and the nearest senior high school in Silat Hulu district. Hence, many parents decided taking their children to reside in the district or in the nearest village with a person who is not their relative.

The phenomenon where students live with no relative while they are attending school in Silat Hulu district is not something new. It has been occurred for many years ago. Hence, there is no one try to find out whether there is relationship between students' residence in the district and students' achievement. In fact, the researchers found a problem in SMAN 1 Silat Hulu. When the researchers did the informal interview to the English teacher of SMAN 1 Silat Hulu, the teacher said that the students had some problems in English subject. The teacher said that there were many students who often do not do their assignment especially their homework, and absolutely it will affect their scores. Besides that, based on the data of English score given by the teacher, the students' scores on daily test, mid-term test, and semester exam are also low. Furthermore, the researchers had done an observation when the students did their learning activities in classroom. Actually, when the students were given a task by the English teacher in classroom, they were able to do the task well, but when the teacher gave them the task on the next day, they could not do the task with the same learning material. Not only that, they were also not able to answer the teacher's question where in fact, the question had been asked by teacher at one meeting before.

The researchers also did the informal interview to the students which were aimed to investigate more about the problem. When the researchers asked them about the reason why they are often do not do their homework, they said, "we do not have enough time to do homework. We live in people's homes, as a result we need to help dong the chores and some of students said "when we finished the chores, we must do another homework either". Consequently, before they study or doing other personal business, they have to do all the home works such as clean the room, wash the dishes, washing clothes, cooking, and if the owner has a store they must serve the customer too, even some of them have to take care of a baby.

Based on the problem and explanation above, the researchers assume that there is a relationship between students' achievement especially English achievement and students' residence while the students are attending school in Silat Hulu district. Moreover, there are some previous studies which examined the 
association between students' achievement and students' residence although almost of the studies were conducted to the college students. Blimling (1989) examined the effects of on-campus versus off-campus living on general student academic performance, academic progress, and retention revealed that living oncampus positively affected academic performance. Astin (1993) found that when compared with commuter students, those living on campus reported more satisfaction with their overall college experience. Astin measured three residency options for college students: at home, in a college residence hall, and in a private room or apartment. The mitigating factor was the distance of the residence from the university. His findings suggested that the most direct effects on students' academic performance were associated with living at home and the distance from home to the university.

Furthermore, Grayson (1997) studied about place of residence, student involvement, and first year marks in the United States. The finding has shown that students living in residence have greater gains in areas such as intellectual development, and are more likely to stay in university and complete their degrees, than students who live off-campus. He also found in the fact that despite their place of residence off-campus and low involvement in some activities, students living with their parents have higher rates of classroom involvement than students living in residence.

In addition, Snyder et al (2011) conducted a research about the relationship of residence to academic performance in NCAA Division I Freshman Athletes. The purpose of this study was to determine if a NCAA Division-I freshman student athlete's place of residence on campus, as opposed to off campus, during his/her freshman year had a statistically significant relationship to academic performance. The results of this study, it was concluded that living in an on campus or off campus environment had no statistical relationship with how the NCAA D-I freshman student athletes performed academically.

Hereafter, the researchers decide to conduct a research about the correlation between students' residence and students' English achievement to the tenth grade students of SMAN 1 Silat Hulu. This research is aimed to investigate whether students' residence correlate with their English achievement or not.

\section{STATEMENT OF THE PROBLEMS}

The following three questions guided this research:

1. How is the English achievement of the tenth grade students of SMAN 1 Silat Hulu?

2. Is there a relationship between students' residence and their English achievement?

3. How significant is the relationship between students' residence and students' English achievement?

\section{RESEARCH METHOD}

Creswell (2012: 337) argued that in educational research, if the objective may be to relate variables rather than manipulate the independent variable, as in an experiment, it means the design is correlational research. Although it is not as 
rigorous as an experiment, the researcher can use it for relating variables or predicting outcomes.

Meanwhile, Ary et al (2010: 349) stated:

Correlational research is non-experimental research that is similar to ex post facto research in that they both employ data derived from preexisting variables. There is no manipulation of the variables in either type of research. They differ in that in ex post facto research, selected variables are used to make comparisons between two or more existing groups, whereas correlational research assesses the relationships among two or more variables in a single group.

Moreover, Wallen \& Fraenkel (2009: 11) defined correlational research as another type of research which is done to determine relationships among two or more variables and to explore their implications for cause and effect. In conclusion, correlational research is non-experimental research where there is no manipulation of variables and the researcher can use it for correlating two or more variables. There are two kinds of correlational research design; they are explanatory design and prediction design. In this research, the researcher uses explanatory design as the research design, where according to Creswell (2012: 340) an explanatory research design is a correlational design in which the researcher is interested in the extent to which two variables (or more) co-vary, that is, where changes in one variable are reflected in changes in the other. The explanatory design is used since the researchers intended to reveal the association between two variables, which are students' residence and students' English achievement.

\section{Population}

A population is a group of individuals who have the same characteristic. A target population (or the sampling frame) is a group of individuals (or a group of organizations) with some common defining characteristic that the researcher can identify and study (Creswell, 2003: 142). The population of this research is the tenth grade students of SMAN I Silt Hula in the academic year 2015/2016.

\section{Sample}

Generally, sample is defined as the sub group of population which is represents the population. Creswell (2012: 142) stated that a sample is a subgroup of the target population that the researcher plans to study for generalizing about the target population. In this research, the researcher uses stratified sampling as sampling technique. In stratified sampling, researchers divide (stratify) the population on some specific characteristic and then, using simple random sampling, sample from each subgroup(stratum) of the population. This guarantees that the sample will include specific characteristics that the researcher wants included in the sample (Creswell, 2012: 144).

The procedure for selecting a stratified random sample consists of (a) dividing the population by the stratum and (b) sampling within each group in the stratum so that the individuals selected are proportional to their representation in the total population (Creswell, 2012: 144). In this research, the researcher dividing 
the population into two strata based on students' residence, they are live with parents, and live with no-relatives.

The minimum acceptable sample size for a correlational study is considered by most researchers to be no less than 30 . Data obtained from a sample smaller than 30 may give an inaccurate estimate of the degree of relationship (Wallen \& Fraenkel, 2009: 335). To determine the sample size in this research, the researchers using tables of random sample sizes in 99\% confidence level. Therefore, in this research the researcher takes 30 students from each stratum.

Table 1. Sample Size

\begin{tabular}{lcc}
\hline Place of Residence & Total Number of Students & Sample \\
Live with parents & 51 & 30 \\
Live with no-relatives & 46 & 30 \\
Other & 15 & - \\
Total & $\mathbf{1 1 2}$ & $\mathbf{6 0}$ \\
\hline
\end{tabular}

\section{Technique of collecting data}

This research used two different kinds of techniques for collecting data as follows:

Directly administered questionnaire, where Ary et al (2010: 387) stated that thedirectly administered questionnaire technique is give the questionnaire to a group of people assembled at a certain place for a specific purpose.In this research, the directly administered questionnaire technique is used to investigate the information from the students based on their residence.

Documentary technique, where Zuldafrial (2012: 39) stated that documentary technique is a method of collecting data where the researcher gather the data or informations which are needed by the important documents that saved. The researcher used documentary technique to find out the students' English achievement from the English teacher of SMAN 1 Silat Hulu.

\section{Instrument of collecting data}

An instrument is a tool for measuring, observing, or documenting quantitative data (Creswell, 2012: 151). Related to the technique that used to collect the data above, the researcher used two kinds of tools as follow:

Questionnaire

The questionnaire is a widely used and useful instrument for collecting survey information, providing structured, often numerical data, being able to be administered without the presence of the researcher, and often being comparatively straightforward to analyze (Wilson and McLean 1994 in Cohen, 2007: 317). In this research, the researcher used closed questionnaire. Closed questionnaire is where the subject of research or the subject that has been given questionnaire just chooses the answer that have ready in the questionnaire (Powell, 1998: 5).

There were 60 items of the questionnaire. The questionnaire was formulated and designed based on the indicators of the sub variables of students' residence. The sub variables were taken from the home environmental factors that influenced 
students' English achievement. The researcher distinguished the questionnaire into two different statements, the positive and negative statement. The description of the indicators was in the table of the specification of the questionnaire.

Table 2. Table of Specification of Students' Residence Variable

\begin{tabular}{|c|c|c|c|}
\hline \multirow{2}{*}{ Sub Variable } & \multirow{2}{*}{ Indicator } & \multicolumn{2}{|c|}{ Number of Item } \\
\hline & & Positive & Negative \\
\hline \multirow[t]{7}{*}{ Parental Involvement } & Fulfill the & $21, \quad 22$, & 23 \\
\hline & learning & $24, \quad 25$, & 29 \\
\hline & facilities & $\begin{array}{l}27, \quad 28, \\
30\end{array}$ & \\
\hline & Controlling & $31, \quad 32$, & $33, \quad 35$, \\
\hline & learning & $34, \quad 36$, & \\
\hline & activities & $37, \quad 39$ & 41 \\
\hline & Encouragement & $\begin{array}{l}44, \quad 45, \\
46, \quad 48, \\
49,50\end{array}$ & 47 \\
\hline \multirow[t]{2}{*}{$\begin{array}{l}\text { Activities Out of } \\
\text { School }\end{array}$} & Structured & $\begin{array}{l}1,2,3,7, \\
8,9\end{array}$ & $4,5,6$ \\
\hline & Unstructured & $\begin{array}{l}10,13,14, \\
15,16,17, \\
18,19,20\end{array}$ & 11,12 \\
\hline
\end{tabular}

The questionnaire in this research used Likert Type questionnaire which consist of four responses option; they are Never (tidak pernah), Seldom (jarang), Often (sering), Very Often (sangatsering). The degree of the scale was described as follow:

Table 3 The Questionnaire Scoring

\begin{tabular}{ccc}
\hline Scale & Positive Statement & Negative Statement \\
& Score & Score \\
Never & 1 & 4 \\
Seldom & 2 & 3 \\
Often & 3 & 2 \\
Very Often & 4 & 1 \\
\hline
\end{tabular}

The questionnaire was made by using Bahasa Indonesia. The goal was to avoid the different perception in understanding the statement in the questionnaire. Additionally, the researcher also presented at the class when the students answered the statements of the questionnaire in order to make sure that the students answered the statements honestly.

Before the questionnaire was used to collect the data, the research has measured the normality, validity and the reliability of the questionnaire. 
Validity

Validity refers to the appropriateness, meaningfulness, correctness, and usefulness of the inferences a researcher makes (Wallen and Fraenkel, 2009: 147). Assessing the validity of score-based interpretations is important to the researcher because most instruments used in educational investigations are designed for measuring hypothetical constructs (Ary et al, 2010: 225). Additionally, Lodico et al (2010: 93) revealed that validity focuses on ensuring that what the instrument "claims" to measure is truly what it is measuring. In this research, the researcher used content validity to test the validity of the questionnaire.

Cohen (2007: 163) stated content validity is achieved by making professional judgments about the relevance and sampling of the contents of the test to a particular domain. It is concerned with coverage and representativeness rather than with patterns of response or scores. Creswell (2012: 162) stated that in content validity the researchers go to a panel of judges or experts and have them identify whether the questions are valid (Creswell, 2012: 162). In order to test the content validity of the questionnaire, the researchers asked the lecturer of IKIPPGRI Pontianak.

\section{Reliability}

Reliability refers to the consistency of the scores obtained how consistent they are for each individual from one administration of an instrument to another and from one set of items to another (Wallen and Fraenkel, 2009: 154). Ary et al (2010: 236) also revealed that the reliability of a measuring instrument is the degree of consistency with which it measures whatever it is measuring. Scores should be nearly the same when researchers administer the instrument multiple times at different times. In this research, the researcher used SPSS 22 to find out the reliability of the questionnaire. The result can be seen as below:

Table 4. The Reliability of Questionnaire

\section{Reliability Statistics}

\begin{tabular}{|r|r|r|}
\hline Cronbach's Alpha & $\begin{array}{c}\text { Cronbach's Alpha Based } \\
\text { on Standardized Items }\end{array}$ & \multicolumn{2}{|c|}{ N of Items } \\
\hline, 899 &, 889 & 50 \\
\hline
\end{tabular}

The data was taken from 30 students who were not included in the sample. Hereafter, the result of the reliability was interpreted in the table below:

Table 5. Category of Reliability

\begin{tabular}{cc}
\hline Reliability & Category of Reliability \\
\hline$r_{11}>0,90$ & Perfect reliability \\
$0,70-0,90$ & High reliability \\
$0,50-0,70$ & Moderate reliability \\
$r_{11}<0,50$ & Low reliability \\
\hline & (Hilton and Brownlow, (2004))
\end{tabular}


The result showed that Cronbach's Alpha was 0,899. It can be concluded that the questionnaire were high reliability.

\section{Normality}

Normality of the data is very important in correlational research. The normality was needed to determine whether the data of the instrument were distributed normally or not. Additionally, normality was also needed to determine whether the researcher used parametric or non-parametric test in analyzing the data. Hence, the researcher tested the normality of the normality of the data from students' English achievement and students' questionnaire. The test had been taken from 60 students who were the sample of this study. The researcher used one sample Kolmogorov-Smirnov test to calculate the normality by using SPSS 22. As the result, the data is normally distributed

\section{Documentation}

In order to get the data about students' English achievement, the researcher used documentation as the instrument. Creswell (2003: 154) stated that document is factual information or personal document which consists of numeric, individual data that available in public records. Examples of these types of data include grade reports, school attendance records, student demographic data, and census information. In this research, the data which was needed to find out the students' English achievement of second semester had been taken from students' book report of second semester in the academic year of 2015/2016.

\section{Technique of Data Analysis}

After getting the data from the students' questionnaire and students' English achievement, the researchers analyzed the data based on the research questions. Before answer the first research question, the researcher described the data of the questionnaire based on the indicators of students' residence ( $\mathrm{X}$ variable).In order to answer the first research question, the researchers calculated the total score of students' English achievement which had been taken from students' book report. Before that the researchers has divided the scores become two groups, the English achievement of the students who live with parents and the students who live with no-relative. After getting the total of students' score from each group, then the researcher search the mean score and interpreted the score based on the scoring grade. The second question of the research is about the correlation between students' residence (X) and students' English achievement (Y). In order to find out the correlation between variable $\mathrm{X}$ and variable $\mathrm{Y}$, the third research question was about the significant correlation between students' residence (X) and students' English achievement (Y).

\section{RESEARCH FINDINGS AND DISCUSSION}

\section{Research Findings}

This study conducted to analyze the data about the correlation between students' residence and students' English achievement. In this research finding, the data about students' residence obtained from the questionnaires which have been given to 60 students. After the data were collected, then the researchers took 
the students English achievement from their report book of the second semester in academic year of 2015/2016. The researchers analyzed the data by applying Pearson Product moment formula to find out whether there was a correlation between students' residence and students' English achievement. Additionally, before the researchers conducted the research, the reliability of questionnaire was done to 30 students of the population who were not including in the sample.

\section{The Description of Data Based On Sub-Variables}

In order to get more details about the result of the questionnaire, the researchers described the data based on the sub-variables of students' residence (X variable). The details as follow:

Student's activities out of school

Students' activities were one of two sub-variables of students' residence. The students were divided into two groups, students live with parents and students live with no relative. In order to find out the data about students activities out of school, the researcher calculated the total answer of respondent of the questionnaire item number 1 until 9 for the frequency of structured activities and item number 10 until 20 for the frequency of unstructured activities from each group. Then the researcher searched the mean score and interpreted them based on the scale below:

Table 6. The interpretation of The Questionnaire Result of Students' Structured Activities

\begin{tabular}{cc}
\hline Score & Interpretation \\
9 & Never \\
$10-18$ & Seldom \\
$19-27$ & Often \\
$28-36$ & Very Often \\
\hline
\end{tabular}

Table 7. The interpretation of The Questionnaire Result of Students' Unstructured Activities

\begin{tabular}{cc}
\hline Score & Interpretation \\
11 & Never \\
$12-22$ & Seldom \\
$23-33$ & Often \\
$34-44$ & Very Often \\
\hline
\end{tabular}

It was found that the mean score of structured activities from the students who live with parents was 29 and the students who live with no relative were 10 . Based on the table above, it could be interpreted that the students who live with parents "Very Often" do the structured activities and the students who live with no relative "Seldom" do the structured activities. Furthermore, the mean score of unstructured activities from the students who live with parents was 36 the students who live with no relative was 33 . It could be interpreted that the students who live with parents "Very Often" do the unstructured activities and the students who live 
with no relative "Often" do the unstructured activities. The comparison can be seen at the figure below.

Figure 1. The Comparison of Students' Activities Out of School

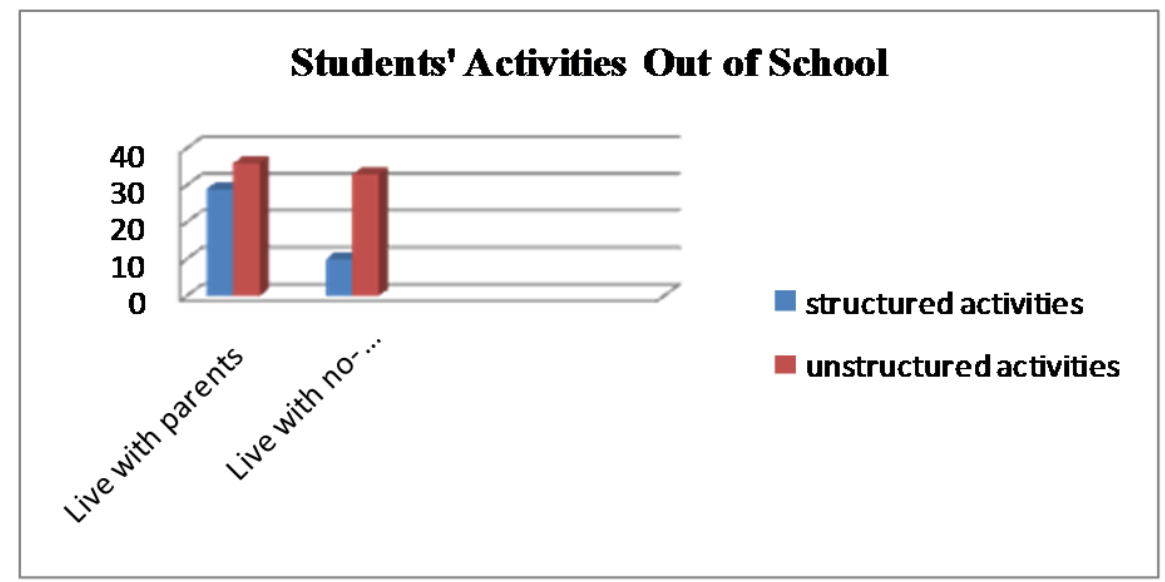

Additionally, the researcher also counted the percentage per indicator of sub variable in order to get more detail about the indicator which influences the students more. There are two indicators of students' activities of school, they were: 1) Structured activities; and 2) Unstructured activities. The data as below:

Table 8. Percentage per Indicator of Students' Activities Out of School

\begin{tabular}{|c|c|c|c|c|}
\hline \multirow[t]{2}{*}{ Sub Variable } & \multirow[t]{2}{*}{ Indicator } & Total & \multicolumn{2}{|c|}{ Students' Residence } \\
\hline & & Item & $\begin{array}{c}\text { With } \\
\text { Parents }\end{array}$ & $\begin{array}{l}\text { With no- } \\
\text { relative }\end{array}$ \\
\hline \multirow{2}{*}{$\begin{array}{c}\text { Activities Out } \\
\text { of School }\end{array}$} & Structured & 9 & $80,93 \%$ & $28,33 \%$ \\
\hline & Unstructured & 11 & $81,59 \%$ & $76,21 \%$ \\
\hline
\end{tabular}

a. Students' parental involvement

The second sub-variable was parental involvement. The students were divided into two groups, students live with parents and students live with no relative. In order to find out the data about parental involvement of the students, the researcher calculated the total answer of respondent of the questionnaire item number 21 until 50 from each group. Then the researcher searched the mean score and interpreted them based on the scale below:

Table 9. The interpretation of the Questionnaire Result

\begin{tabular}{cc}
\hline Score & Interpretation \\
30 & Never \\
$31-60$ & Seldom \\
$61-90$ & Often \\
$91-120$ & Very Often \\
\hline
\end{tabular}


It was found that the mean score of the students who live with parents was 103. Based on the table above, it could be interpreted that the parents of the students who live with parents "Very Often" involve in their children learning process. On the other side, the mean score of the students who live with no relative was 87 . It could be interpreted that the parents of students who live with no relative "often" involve in their children learning process.

Furthermore, the researchers identified the percentage per indicator of parental involvement. There were three indicators of parental involvement. The first was fulfilling the learning activities. The second was controlling learning activities both at home and at school. The last was the encouragement of parents. The data as below:

Table 10. Percentage per Indicator of Parental Involvement

\begin{tabular}{|c|c|c|c|c|}
\hline \multirow[t]{2}{*}{ Sub Variable } & \multirow[t]{2}{*}{ Indicators } & Total & \multicolumn{2}{|c|}{ Students' Residence } \\
\hline & & Item & $\begin{array}{c}\text { With } \\
\text { Parents }\end{array}$ & $\begin{array}{l}\text { With No- } \\
\text { Relative }\end{array}$ \\
\hline \multirow[t]{3}{*}{$\begin{array}{c}\text { Parental } \\
\text { Involvement }\end{array}$} & $\begin{array}{l}\text { Fulfill the learning } \\
\text { facilities }\end{array}$ & 10 & $86,67 \%$ & $76,42 \%$ \\
\hline & $\begin{array}{l}\text { Controlling } \\
\text { learning activity }\end{array}$ & 13 & $89,04 \%$ & $77,05 \%$ \\
\hline & Encouragement & 7 & $77,50 \%$ & $59,64 \%$ \\
\hline
\end{tabular}

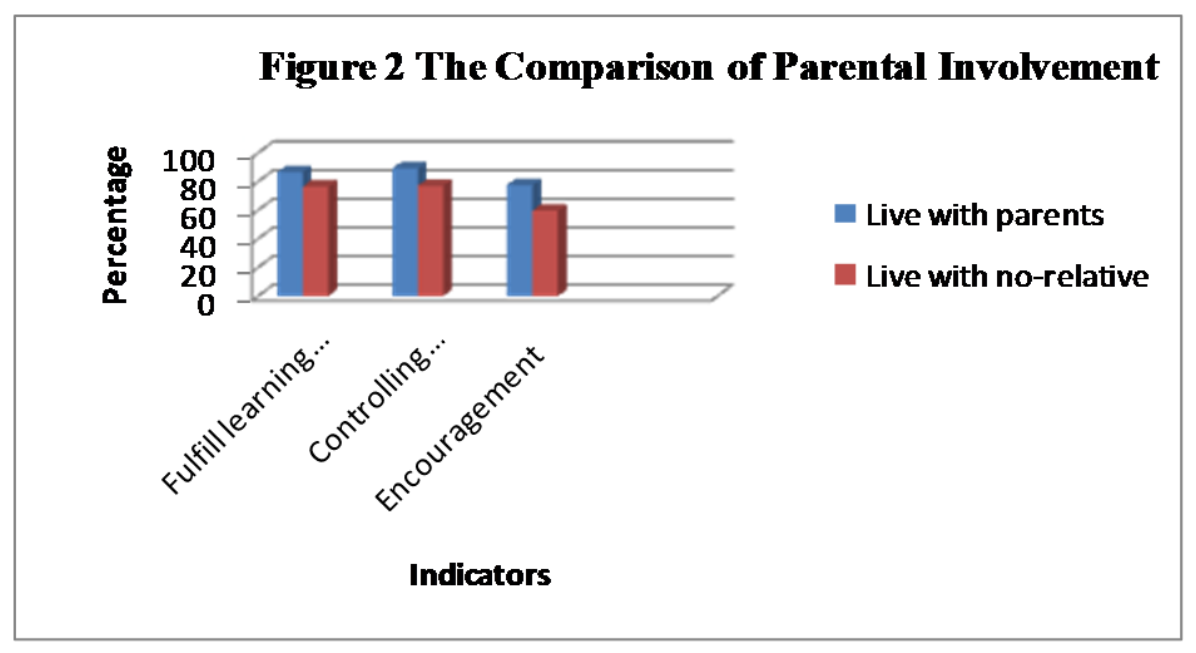

\section{The Students' English Achievement}

The first question of this research was about students' English achievement. In order to answer the question, the researchers collected the data from students' book report and they have been calculated. Then, the students' score can be generally classified into five grades as follows: 
Table 11. The Scoring for English Achievement

\begin{tabular}{cc}
\hline Score & Grade \\
$80-100$ & Excellent \\
$70-79$ & Good \\
$60-69$ & Average \\
$50-59$ & Bad \\
$0-49$ & Poor \\
\hline
\end{tabular}

The students' English achievement was divided into two categories, the English achievement of the students who live with parent and the English achievement of the students who live with no-relative. It can be the mean score of students who live with parent was 76, 30, hence the grade was "Good" achievement. On the other side, the mean score of the students who live with norelative was 69, 93 with grade "Average" achievement. It means that the students who live with parents have the higher achievement than the students who live with no-relative.

\section{The Correlation between Students' Residence and Students' English Achievement}

The second research question was whether any correlation between students' residence and students' English achievement or not. To answer the second research question, the researchers calculated the data through Pearson Product Moment formula. Before calculating the data, the descriptive score below are the result of $\mathrm{X}$ and $\mathrm{Y}$ score:

$$
\begin{aligned}
\mathrm{N} & =60 \\
\sum \mathrm{X} & =9370 \\
\sum \mathrm{Y} & =4387 \\
\sum \mathrm{XY} & =689368 \\
\sum \mathrm{X}^{2} & =1492502 \\
\sum \mathrm{Y}^{2} & =321993
\end{aligned}
$$

After the calculation of the whole data from variable $\mathrm{X}$ and variable $\mathrm{Y}$, the next step was calculated the correlation of the two variables by using Pearson Product moment formula.

From the calculation above, it was known that $r=0,71$. In order to interpret it, the researchers used the table below:

Table 12. Practical Interpretations of Correlation Coefficients

\begin{tabular}{ll}
\hline \multicolumn{1}{c}{ Correlation Coefficient } & \multicolumn{1}{c}{ Strength of Relation } \\
0 to 0.19 & No relationship or weak relationship \\
0.20 to 0.34 & Modest relationship \\
0.35 to 0.64 & Moderately strong relationship \\
0.65 to 0.84 & Strong relationship \\
0.84 or greater & Very strong relationship \\
\hline
\end{tabular}


(Lodico et al (2010: 104))

Based on the table above, it could be interpreted that $r=0,71$ means strong relationship. Hence, the researchers concluded that the relationship between students' residence and students' English achievement is strong relationship.

\section{The Significant Correlation between Students' Residence and Students' English Achievement}

The third research question was about the significant relationship between students' residence and students' English achievement. In order to answer the third research question, the researchers used test formula. The next step was compare the result of $t_{\text {count }}=7,71$ with $t_{\text {table }}$ with $\alpha=0,025$ and the degree of freedom 58. Hence, $\mathrm{t}_{\text {table }}=\mathrm{t}_{(0,975),(58)}=\mathrm{t}_{(0,025),(58)}=2,000$. It can be seen that $\mathrm{t}_{\text {count }}=$ 7,71 is bigger than $t_{\text {table, }}$, so Ho was rejected. It means that Ha was accepted, that was there was a significant correlation between students' residence and students' English achievement.

\section{DISCUSSION}

Based on the result of students' English mean score, it was found that the mean score of the students who live with parents was higher than the students who live no relative. The researchers also found that there was a significant correlation between students' residence and students' English achievement. This finding was consistent with the studies of Blimbing (1989), Astin (1993), and Grayson (1997) which examined that there was correlation between students' residence and their academic performance. However, the current finding was contradict with finding of Snyder et al (2011) which concluded that students' residence had no statistical relationship with how the freshman students performed academically.

Moreover, the finding based on the indicator of students activities out of school indicated that the harmony between structured activities and unstructured activities which the students do at their each residence type had a great association with students' achievement. This finding is in agreement with Won \& Han (2010) which concluded that structured had positive predictor of students' achievement. Further finding based on the the indicator of parental involvement reveal that the parental involvement in students' learning had positive correlation with students' English achievement. This finding in line with the result of Olaniyi \& Mageshni (2008) which show that parental involvement positively correlated with students' academic achievement.

\section{CONCLUSION AND SUGGESTION}

There was a difference mean score between students who live with parents and the students who live with no relative. The students who live with parents got the English achievement higher than the English achievement of the students who live with no relative. The students who live with parent got score 76,30 in average with the category "Good Achievement", where the students who live with no relative got score 69,93 in average with category "Average Achievement". There was a correlation between students English achievement and students residence 
with two sub variables (activities out of school and parental involvement). The correlation which occured was a strong correlation with correlation coefficient 0,71 .

Based on the calculation of significant correlation by using T-test formula, it was found that there was a significant relationship between students residence and students English achievement in the tenth grade students of SMAN 1 Silat Hulu in the academic year of 2015/2016. The significant value was $7,71\left(\mathrm{t}_{\mathrm{value}}\right)$ where it was bigger than $t_{\text {table }}=1,960$, hence the alternative hypothesis was accepted. Therefor, there was a significant correlation between students residence as $\mathrm{X}$ variable and students English achievement as $\mathrm{Y}$ variable to the tenth grade students of SMAN 1 Silat Hulu.

Additionally, the researchers give some suggestions from the result of the research involved the suggestion for teachers, students, and others researchers. Some suggestions related to the result of the study proposed. The suggestion for the teachers to give the advice for the students about students learning at school and especially learning activities, and the teachers also can give the suggestion and tips about study at home although the students have many things to do. Meanwhile, It is suggested for the students to always study English not only at school but also at home and make a good schedule about their daily activities, so although the students have many activities to do they still have time to learn specially English subject at home. The last for other researchers, this research is able to be a reference researcher who intend to do the same research to develop the indicators of the students residence, therefor the result will be more detail and accurate.

\section{REFERENCES}

Ary, D., Jacobs, L. C., \&Razavieh, A. (2010). Introduction to Research In Education 8th Edition. USA: Wadsworth.

Astin, A. (1993). What matters in college? Review by David A. McKelfresh.San Francisco: Jossey-Bass.

Blimling, G. S. (1989). A meta-analysis of the influence of college residence halls on academic performance. Journal of College Student Development, 30, 298-308.

Cohen, L., Manion, L., \& Morrison, K. (2007). Research Methods in Education, Sixth Edition. New York: Rouledge.

Collins, A. I. (2007). Social Studies for Schools. Ibadan: University Press Ltd.

Creswell, J.C. (2012). Education Research, Planning, Conducting and Evaluating Quantitative and Qualitative Research. 4th edition. Boston: Pearson.

Creswell, J. W. (2003). Educational Research: Planning, Conducting, and Evaluating Quantitative andQualitative Research 4th ed. Boston: PearsonEducation, Inc. 
Egunsola, A.O.E. (2014). Influence of Home Environment on Academic Performance of Secondary School Students in Agricultural Science in Adamawa State Nigeria. IOSR Journal of Research \& Method in Education (IOSR-JRME), Volume 4, Issue 4 Ver. II (Jul-Aug. 2014), PP 46-53.

Fraenkel, J. R. \& Wallen, N. E. (2009). How to Design and Evaluate Research in Education Seventh Edition. New York: McGraw-Hill.

Grayson, J. P. (1997). Place of Residence, Student Involvement, and First Year Marks.The Canadian Journal of Higher Education, Volume XXVII1,1997, pages 1-24.

Lodico et al. (2010). Methods in Educational Research: From Theory to Practice. USA: Jossey-Bass.

Ogbemudia, M. I. \& Aiasa, M. V. (2013). Influence of home environment on the academic performance of primary five pupils' in English Language in Orhionmwon Local Government Area of Edo State Merit Res. Journal of Ed. and Rev., 1 (5), $120-125$.

Powell, E. T. (1998). Questionnaire Design: Asking Questions With A Purpose. Texas: College Station.

Snyder, E. M. et al. (2011). The Relationship of Residence to Academic Performance in NCAA Division I Freshman Athletes.Journal of Issues in Intercollegiate Athletics, 2011, 4, 105-119.

Zuldafrial. (2012). Penelitian Kuantitatif. Yogyakarta: Media Perkasa. 